\title{
Embedding Sustainability into the Tourism Planning Process: Evidence from Michigan
}

\author{
Sarah Nicholls
}

Department of Business, Swansea University, Bay Campus, Swansea SA1 8EN, UK

Corresponding Author Email: Sarah.Nicholls@Swansea.ac.uk

https://doi.org/10.18280/ijsdp.160105

Received: 2 December 2020

Accepted: 9 February 2021

\section{Keywords:}

collaboration, convention and visitors bureau (CVB), participation,

stakeholders, tourism

\begin{abstract}
Sustainability has become a common term in the lexicon of most tourism scholars and many industry professionals. Yet active infusion of sustainability thinking and initiatives in practice remains less consistent. This exploratory study investigates awareness and understanding of, and engagement with, sustainability concepts and practices by those involved in - or having the ability to influence - tourism planning. A survey of tourism office directors and planners reveals limited and divergent understanding of the basic underlying characteristics of sustainability amongst these two critical stakeholders groups, both of which are core to the planning, development, marketing and management of tourism. Findings suggest the need for continued effort to translate the huge volume of sustainability-focused tourism research into terms and formats more digestible by industry professionals, as well as opportunities for local entities to take the lead in bringing diverse stakeholders together to drive a greater emphasis on sustainability within their communities.
\end{abstract}

\section{INTRODUCTION}

A focus of tourism research for several decades, the concept of sustainability has also become an increasingly common topic of conversation amongst tourism industry professionals. Yet the extent to which, and the reasons why, practitioners are actively infusing sustainability thinking and initiatives into their work remain less clear or consistent than they do amongst researchers.

Opportunities to adopt more sustainable practices vary with an organisation's place in the tourism supply chain. Whilst site-specific providers with direct visitor contact might focus on operational changes (e.g., hotels or attractions might emphasise increasing energy efficiency and recycling, and reducing energy and water use), entities operating at earlier stages in the tourism system enjoy greater ability to influence the consideration of sustainability during the planning and development phases of both individual sites and entire destinations. There is a burgeoning literature on the former, with a host of studies presenting analyses of opportunities for - and rates and impacts of - the implementation of green practices from both supply and demand perspectives across a range of sectors (see, e.g., recent reviews of the accommodation and restaurant sectors [1-3]).

There seems to date to have been less attention paid to the latter, however, and the limited evidence available suggests a lingering gap between rhetoric and reality. In the context of New Zealand, for example, Connell, Page and Bentley [4] concluded that, "While sustainability is now one of the cornerstones of New Zealand tourism strategy, much of this lies at a national, strategic level and remains as a philosophical stance. Yet, the perception of New Zealand as at the forefront of sustainable policy developments is not matched in reality ...". Ruhanen [5] succinctly summarises a variety of other evidence regarding the disconnect between discussion of sustainability in theory and its implementation within destinations in practice.

This paper attempts to redress this dearth of evidence regarding consideration of sustainability principles in the planning phase of tourism development and by the individuals and organisations that support and facilitate tourism rather than frontline providers of tourism services. This focus on planning recognises the fragmented nature of the industry and its many crossovers with resources and issues relevant to the wider community and environment in which tourism takes place, challenges which provide further rationale for the active involvement of all relevant stakeholders - beyond providers during and after the planning and inception stages. The purpose of this exploratory study was therefore to investigate awareness and understanding of, and engagement with, sustainability concepts and practices by those involved in, or having the ability to influence, the tourism planning phase. More specifically, it asked questions regarding actual and perceived desirable levels of involvement in tourism planning, understanding of the term 'sustainable tourism,' and perceptions of who holds primary responsibility for planning for sustainable tourism in destinations. Its focus was the local level (city and county) in a US context, and the two key constituency groups involved were directors of local tourism offices and local planning officials.

The study did not favour any single or formal definition of sustainability. Rather, it took a broad approach to the concept, recognising the relevance and importance of economic, sociocultural, political/institutional, technological and environmental factors; a host of stakeholders including though not limited to tourists, residents, industry and all levels of government; and, conditions and experiences in both present and future timeframes. 


\section{LITERATURE REVIEW}

\subsection{Sustainable tourism (planning)}

Sustainable tourism has been described as a "way of doing planning, policy and development to ensure that tourism benefits are equitably distributed between all stakeholders" [6]; the focus here is on the first of these activities, planning and the planning process. While planning can take place at a multitude of scales, from the individual site (transportation hub, hotel, attraction, etc.) to the national and international levels, the focus here is on destinations, i.e., places such as towns, cities or counties that attract visitors to them as a result of some combination of attractions and supporting tourism infrastructure. The need to plan (for) tourism derives not only from its economic significance - typically measured in terms of numbers of visitors to a destination, volume of associated direct, indirect and induced spending, and the creation of jobs - but also from its inseparability. Unlike traditional products, which consumers acquire from a retail environment for later use, tourists must travel to the site of provision - the tourism destination - to engage in tourism experiences. The presence of these visitors - in places that are other people's homes and include sometime fragile natural ecosystems - and their interactions with those places and their residents - can have substantial impacts on local society, culture and environment. Tourism planning can therefore be envisaged as a mechanism via which both to make destinations more attractive to visitors though also to minimise tourism's negative impacts [7].

Tourism planning has been characterised as passing through at least five key phases, as originally identified by Getz [8] and more recently extended by Hall [7]; these include boosterism; economic/industry; physical/spatial/environmental; community; and, sustainable. While earlier phases emphasised the economic benefits of tourism, taking a pro-growth, industry-oriented approach, later ones have progressively identified the critical need to manage and protect resources and the environment, and to consider the opinions and needs of those impacted by tourism development. The most inclusive of all, a sustainable planning approach, encapsulates all of the key characteristics outlined above, emphasising understanding of the need to balance economic, social and environmental considerations; look beyond tourism growth and tourist satisfaction to community welfare and quality of life; and, consider present and future generations. Despite the generally recognised shift to a sustainable approach, however, limited, incomplete and/or variable understanding of the core elements of sustainability have continued to be referenced in the literature [9, 10].

Incorporation of sustainability principles in tourism plans and planning processes

Simpson [6] developed an evaluation framework against which to assess the extent to which a tourism plan incorporates sustainability principles. The resulting instrument included 51 criteria cutting across five categories - stakeholder participation (13 criteria), vision and values (6), situation analysis (15), goals and objectives (12) and implementation and review (5). Simpson tested his proposed framework in New Zealand, based on analysis of 26 sub-national tourism strategy documents by himself and three other reviewers.

Ruhanen $[5,11]$ used Simpson's evaluation tool to assess levels of integration of sustainability practices into 30 tourism plans in Queensland, Australia. She concluded that "the plans were generally found not to be meeting the sustainable planning criteria". Follow-up interviews with representatives from the five best performing localities revealed that even in those places where sustainability principles underpinned their policy documents, limited understanding of those principles or of how to integrate and apply them in practice remained a key inhibitor to the realisation of more sustainable tourism development [12]. Also in an Australian context, Baggio and Marzano [13] concluded that sustainability thinking was not fundamental to Tourism Queensland's destination management plans.

A comprehensive analysis of 339 Australian tourism strategic planning and policy documents published between 2000 and 2011 revealed that whilst reference to sustainability remained relatively low across the period, the dimensions emphasised did shift somewhat [14]. Unique reference to the term 'sustainability' in the plans held steady at just $2 \%$ of all concepts cited; reference to sustainability as an overarching theme increased from $16 \%$ of all concepts between 2000 and 2005 to $17 \%$ in $2006-2011$.

Simpson's instrument was also employed by Simão and Partidário [15] to review 11 local/regional plans in Portugal. The authors concluded that, "The plans speak of sustainability, but few say what they mean by this. When they do, they use a very generic approach ... and an implicit or explicit kind of weak sustainability is suggested". They go on to note the general lack of consideration of sustainability principles in Portuguese tourism planning. A review of 55 international, European and Spanish institutional documents similarly highlighted the ambiguity inherent in definitions and understandings of sustainability, rendering many of the initiatives assessed "too utopian and generic for practical application" [16].

\subsection{Measuring the achievement of sustainable tourism}

A recurring theme in the studies summarised above has been the lack of tools via which to implement - and to then gauge levels of success around implementation of sustainability practices. Many methods via which to assess sustainability have in fact been developed (e.g., ecological footprint analysis [17] and yield analysis [18]), though no one has yet emerged as preferred, whether amongst researchers or professionals. Another such type of measurement tool are sustainability indicators. Multiple sets of tourism sustainability indicators have now been developed [9-23].

Choi and Sirakaya [24] developed a widely cited set of 125 indicators designed to assess achievement of sustainable community tourism development. A similar set of indicators targeted at established destinations expanding into the rural tourism market - was designed by Blancas et al. [25].

More recent studies have deployed a range of sophisticated non-linear techniques to assess destination sustainability, e.g., network analysis [26], genetic algorithms [27] and systems dynamics and neural networks [28]. The utility of these approaches by tourism offices or businesses is, however, questionable given their technically advanced natures and the specialist expertise and softwares required.

Though offering important contributions regarding planning and implementation processes, many of the studies above appear to share a common assumption, namely a basic awareness and level of understanding of sustainability as a concept and/or in practice on the part of participants. Moreover, the results of some of them suggest that this supposition is perhaps optimistic. This study therefore takes a 
step back, focusing on the fundamental issue of the extent to which various local-level stakeholders are aware of, have an understanding of, and engage with, sustainability concepts during the tourism-related activities in which they engage.

\section{METHOD}

\subsection{Study area}

The study was conducted in the state of Michigan, an increasingly popular leisure destination in the Great Lakes area of the United States. In 2017, Michigan hosted 122.4 million visits representing $\$ 24.7$ billion in earnings, a rise of $4 \%$ over the year prior. Tourism is estimated to account for $6 \%$ of jobs across the state, making it the eleventh largest employer [29]. The growth of the industry has been heavily promoted by the incredibly successful Pure Michigan marketing campaign, introduced to regional markets in 2006 and (inter)national markets in 2009 [30]. Though a boon to the economy, some destinations have nevertheless more recently been subject to tourism-related growth pressures that have ignited debate regarding volumes of visitors and speed of industry growth $[31,32]$.

Michigan is divided into 83 counties. There are 48 destination marketing organizations (Convention and Visitors Bureaus, CVBs) operating throughout the state, some of which focus solely on bringing in visitors to their areas, and some of which are combined with Chambers of Commerce (CoCs) that have a broader mandate to also assist all small businesses and to enhance economic growth within their constituencies. Counties each have an elected board of commissioners that serves as the legislative body; each county also has a series of standing and ad hoc committees that include one focused on land use, planning and zoning. Similarly, townships within counties each have some kind of appointed planning entity that reviews and makes recommendations regarding proposed developments to the township Board of Trustees.

\subsection{Data collection and analysis}

A short survey was designed to elicit the following from respondents: their organisation's primary purpose or function; actual/current and desirable/future levels of engagement in a variety of work functions including tourism planning; existence of a tourism development plan in the respondent's county; understanding of the term 'sustainable tourism;' and, opinions regarding which entity(ies) hold(s) primary responsibility for planning for sustainable tourism in the respondent's county. Perceptions of the importance and size of the local tourism industry were also assessed.

The survey was administered online, between August and October 2019, using Qualtrics software. Invitations to participate were emailed to two key groups of individuals: (i) the directors of all Michigan CVBs $(\mathrm{N}=48)$ and (ii) a sample of 691 county and township planners and planning commission members. Three reminders were sent to each group. Response rates were as follows: CVB directors, $n=36$, response rate of $75.0 \%$ representing 36 distinct CVBs and 30 of Michigan's 83 counties; and, county/township planners, $\mathrm{n}=128$, response rate of $20.8 \%$ after accounting for 75 undeliverable invitations, representing 106 distinct entities and 44 different counties. Though the sample size for CVBs is small, the corresponding population is also limited and the rate of response compares very favourably to those in similar studies (e.g., Connell, Page and Bentley [4] received a $51 \%$ response rate from 85 local authorities surveyed across New Zealand). Responses were received from all across the state, including both the Upper and Lower Peninsulas, high and low volume destinations, and rural and urban areas.

Descriptive statistics were used to characterise the majority of responses. Difference of means procedures were employed to identify any significant differences in response between the two study groups, and a basic thematic analysis was carried out to summarise responses to open-ended questions.

\section{FINDINGS AND DISCUSSION}

\subsection{Purpose or function of organization}

The first question in the survey was open-ended and asked respondents to describe the primary purpose or function of their organization. This question allowed identification of the extent to which any planning or sustainability-related activities were noted without any prompting. No CVB directors listed any kind of tourism planning function or involvement in the implementation of sustainability initiatives. Rather, the majority emphasised their roles as tourism promoters and marketers in the pursuit of enticing visitors to and/or boosting spending in their destinations; $47 \%$ of directors specifically mentioned destination promotion and another $47 \%$ mentioned destination marketing, with $11 \%$ listing both. All others that did not use these specific terms nevertheless provided a description that implied these functions, e.g., "bringing in overnight guests." Nearly $27 \%$ of CVB directors referred to their role in broader economic or community development or growth and $19 \%$ alluded to the welfare of the community, e.g., making a place a better one in which to live and work; though these responses do suggest an approach that thinks beyond a pure focus on numbers of visitors, no respondent fully articulated a conscious focus on the full range of sustainability dimensions in terms of tourism's broader impacts across the community both now and with respect to future generations. Amongst the planning officials, no response included the word sustainability though one (less than 1\%) alluded to the concept; most $(66 \%)$ described their function in terms of general tasks typical of county or local government (e.g., providing essential services such as health care, education and emergency assistance; zoning, etc.).

\subsection{Importance and size of tourism industry}

Tourism was widely perceived as of great importance to the economy of the respondent's home county; tourism was indicated as extremely important by $89 \%$ of CVB respondents and $81 \%$ of planners (Table 1). Opinions with respect to the extent of the industry were a little more varied, however. Though no CVB respondents considered the industry to be too large (to the point that their community receives too many visitors), $11 \%$ of planning officials did indicate that perception, suggesting recognition by a small proportion of this group of some of the negative implications of growing visitor volume. Most planning officials (59\%) perceived industry size and numbers of visitors to be about right, while most CVB directors $(53 \%)$ desired a larger industry and more visitors (Table 2). This emphasis on visitation reflects the traditional mandate of CVBs, to "put heads in beds" as a result of their 
marketing/promotional activities. Again, this finding emphasises the lack of awareness amongst CVB directors of the potential negative consequences of too many visitors/too much tourism, despite the rising coverage of 'over-tourism' in the media and in academic writing in recent years, including within the study area as referenced in the preceding section.

Table 1. Importance of tourism to economy in county

\begin{tabular}{c|c|c|c|c}
\hline \multirow{2}{*}{} & \multicolumn{2}{|c|}{ CVBs (n=34) } & \multicolumn{2}{c}{$\begin{array}{c}\text { Planning Officials } \\
(\mathrm{n}=128)\end{array}$} \\
\cline { 2 - 5 } & $\mathrm{n}$ & $\%$ & $\mathrm{n}$ & $\%$ \\
\hline Not at all & 0 & 0.0 & 1 & 0.8 \\
\hline A little & 0 & 0.0 & 0 & 0.0 \\
\hline Somewhat & 2 & 5.6 & 23 & 18.0 \\
\hline Extremely & 32 & 88.9 & 104 & 81.3 \\
\hline
\end{tabular}

Table 2. Size of tourism industry in county

\begin{tabular}{c|c|c|c|c}
\hline \multirow{2}{*}{} & \multicolumn{2}{|c|}{$\begin{array}{c}\text { CVBs } \\
(\mathrm{n}=30)\end{array}$} & \multicolumn{2}{c}{$\begin{array}{c}\text { Planning Officials } \\
(\mathrm{n}=128)\end{array}$} \\
\cline { 2 - 5 } & $\mathrm{n}$ & $\%$ & $\mathrm{n}$ & $\%$ \\
\hline $\begin{array}{c}\text { Too small/we need more } \\
\text { visitors }\end{array}$ & 16 & 53.3 & 39 & 30.5 \\
\hline About right & 14 & 46.7 & 75 & 58.6 \\
\hline $\begin{array}{c}\text { Too large/we receive too } \\
\text { many visitors }\end{array}$ & 0 & 0 & 14 & 10.9 \\
\hline
\end{tabular}

\subsection{Organizational activities and existence of a tourism plan}

A pair of questions provided respondents with a list of eleven activities, for each of which they were asked to indicate current and desirable levels of engagement. Difference of means tests were conducted between the two groups (i.e., of CVB directors and planning officials) for both current and desirable levels, and within each group between current and desirable levels. Respondents were also asked whether a standalone tourism development plan \{that covers more than marketing\} existed for their community (emphasis as in survey instrument).

As anticipated, respondents from CVBs were unanimous in their indication of tourism marketing as a core activity (with $94 \%$ of respondents indicating that their organization currently engages in marketing 'to a great extent' and a mean of 3.9 out of 4.0). Coordinating and building partnerships with tourism stakeholders and enhancing visitors' experiences were almost as frequently engaged in (means of 3.8 and 3.7); mean scores were significantly higher for CVB directors than planners on all three of these items, as to be expected given the traditional roles of the CVB. The lowest mean score for CVBs (2.6) was indicated for anticipating/managing crises; contributing to the protection of sensitive natural areas received a mean of 2.7 though the distribution of responses was bimodal, with $36 \%$ of CVB directors indicating they do so 'a little' but 33\% 'to a great extent.'

For planning officials, in contrast to CVBs though as expected given their traditional job functions, tourism marketing and attracting conventions and other events were the least commonly engaged in activities (means 2.0 and 1.7, respectively, both significantly lower than those for CVBs). Instead, planning officials saw their organisations as focusing on place making (mean 3.4) and contributing to economic development and the protection of sensitive natural areas (both 3.3). These means were only significantly different to CVB responses (higher for planning officials) in the latter case (Table 3).

Table 3. Extent to which organization currently engages in activities (n and (\%), CVBs (top of each row) and planning officials (bottom of row)

\begin{tabular}{|c|c|c|c|c|c|c|}
\hline & Not At All & A Little & Somewhat & $\begin{array}{c}\text { To a Great } \\
\text { Extent }\end{array}$ & $\begin{array}{c}\text { Mean } \\
\text { (out of 4) }\end{array}$ & Unsure \\
\hline \multirow{2}{*}{ Tourism marketing } & 0 & $2(5.6)$ & 0 & $34(94.4)$ & $3.9 * *$ & 0 \\
\hline & $53(41.1)$ & $37(28.7)$ & $25(19.4)$ & $13(10.1)$ & $2.0 * *$ & $1(0.8)$ \\
\hline \multirow{2}{*}{ Enhancing visitors' experiences } & 0 & $1(2.8)$ & $9(25.0)$ & $26(72.2)$ & $3.7 * *$ & 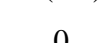 \\
\hline & $18(14.0)$ & $28(21.7)$ & $36(27.9)$ & $44(34.1)$ & $2.8 * *$ & 0 \\
\hline \multirow{2}{*}{ Attracting conventions and other events } & $3(8.3)$ & $8(22.2)$ & $8(22.2)$ & $17(47.2)$ & $3.1 * *$ & 0 \\
\hline & $69(53.5)$ & $35(27.1)$ & $18(14.0)$ & $6(4.7)$ & $1.7 * *$ & $1(0.8)$ \\
\hline \multirow{2}{*}{ Anticipating/managing crises } & $6(16.7)$ & $10(27.8)$ & $11(30.6)$ & $8(22.2)$ & 2.6 & $1(2.8)$ \\
\hline & $19(14.7)$ & $24(18.6)$ & $37(28.7)$ & $46(35.7)$ & 2.9 & $3(2.3)$ \\
\hline \multirow{2}{*}{ Tourism planning } & 0 & $3(8.3)$ & $8(22.2)$ & $25(69.4)$ & $3.6 * *$ & 0 \\
\hline & $37(28.7)$ & $42(32.6)$ & $37(28.7)$ & $10(7.8)$ & $2.2 * *$ & $3(2.3)$ \\
\hline Identifying/implementing sustainability & $4(11.1)$ & $8(22.2)$ & $15(41.7)$ & $9(25.0)$ & 2.8 & 0 \\
\hline initiatives & $6(4.7)$ & $28(21.7)$ & $46(35.7)$ & $42(32.6)$ & 3.0 & $7(5.4)$ \\
\hline Coordinating/building partnerships with tourism & 0 & $1(2.8)$ & $6(16.7)$ & $29(80.6)$ & $3.8 * *$ & 0 \\
\hline stakeholders & $22(17.1)$ & $33(25.6)$ & $39(30.2)$ & $34(26.4)$ & $2.7 * *$ & $1(0.8)$ \\
\hline \multirow{2}{*}{$\begin{array}{l}\text { Place making (creating a better place for } \\
\text { residents and visitors) }\end{array}$} & 0 & $5(13.9)$ & $11(30.6)$ & $19(52.8)$ & 3.4 & $1(2.8)$ \\
\hline & $4(3.1)$ & $13(13.2)$ & $32(38.0)$ & $77(59.7)$ & 3.4 & $3(2.3)$ \\
\hline \multirow{2}{*}{ Contributing to economic development } & $1(2.8)$ & $3(8.3)$ & $8(22.2)$ & $23(63.9)$ & 3.5 & $1(2.8)$ \\
\hline & $6(4.7)$ & $13(10.1)$ & $44(34.1)$ & $64(49.6)$ & 3.3 & $2(1.6)$ \\
\hline \multirow{2}{*}{$\begin{array}{l}\text { Contributing to the protection of sensitive natural } \\
\text { areas }\end{array}$} & $4(11.1)$ & $13(36.1)$ & $16(16.7)$ & $12(33.3)$ & $2.7 *$ & $1(2.8)$ \\
\hline & $7(5.4)$ & $20(15.5)$ & $32(24.8)$ & $67(51.9)$ & $3.3^{*}$ & $3(2.3)$ \\
\hline \multirow{2}{*}{$\begin{array}{c}\text { Contributing to the preservation of cultural } \\
\text { heritage }\end{array}$} & $3(8.3)$ & $7(19.4)$ & $13(36.1)$ & $11(30.6)$ & 2.9 & $2(5.6)$ \\
\hline & $12(9.3)$ & $25(19.4)$ & $41(31.8)$ & $45(34.9)$ & 3.0 & $6(4.7)$ \\
\hline
\end{tabular}

* means different at $0.05, * *$ means different at 0.01

Curiously, given this activity's complete absence from the open-ended responses, tourism planning ranked as the fourth most frequently engaged in of the eleven activities listed among CVB respondents (with $69 \%$ of respondents indicating that their organization currently engages in planning 'to a great extent' and a mean of 3.6 out of 4.0). Meanwhile tourism planning was not identified as a common activity by the responding planning officials (mean 2.2), despite planning 
officials virtually unanimous recognition of the important of tourism to their area's economy. Of the six CVB directors that indicated there is a tourism-specific development plan for their community (with the question worded to stress a plan that covers more than marketing, as noted above), none were able to provide such a plan when this was later requested; instead, a traditional marketing plan was shared. It would therefore seem likely that CVBs interpreted 'planning' in the context of trip or vacation planning, rather than land use or development planning, suggesting a serious challenge with respect to the lack of a basic shared vocabulary between those best placed to influence the speed and extent of tourism growth (Table 4).

Fifty percent of CVB directors and $37 \%$ of planning officials believed that while there was no tourism-specific development plan for their community, tourism is included within the overall master plan. While $19 \%$ of CVB directors and $24 \%$ of planners did not believe any kind of plan for tourism to exist, over $30 \%$ of the latter were unsure, a troubling proportion given their responsibility for community planning, the presence of the tourism industry in every county from which responses were received, and planning officials' perceived estimate of tourism's economic importance.

Subsequent investigation of approximately one-half of the state's counties (41 of 83) revealed complete online versions of current or recent master plans in 25 cases. Of the 25 , just one master plan mentioned tourism in its vision, with two more including one or more tourism-specific goals or objectives (though in one of those cases most items were marketing/promotions-related). Tourism was indeed mentioned in every other plan, though typically in passing rather than in a standalone section. To the best of the author's knowledge, there are no publicly-available county- or local-level destination management (as opposed to narrower marketing) plans across the state. Ruhanen [5, 11] noted that of the 125 local destinations in her study area (Queensland, Australia), 24\% had a tourism-specific planning document, suggesting Michigan is behind the curve is this respect. Tameling [33] found that $22 \%$ of municipalities engage in tourism planning and policymaking in a Dutch context, a low proportion but again superior to Michigan-based activity.

Table 4. Existence of a tourism development plan for community

\begin{tabular}{c|c|c|c|c}
\hline \multirow{2}{*}{} & \multicolumn{2}{|c|}{$\begin{array}{c}\text { CVBs } \\
(\mathrm{n}=34)\end{array}$} & \multicolumn{2}{c}{$\begin{array}{c}\text { Planning } \\
\text { Officials } \\
(\mathrm{n}=128)\end{array}$} \\
\cline { 2 - 5 } & $\mathrm{n}$ & $\%$ & $\mathrm{n}$ & $\%$ \\
\hline $\begin{array}{c}\text { Yes, there is a tourism-specific } \\
\text { plan for the community }\end{array}$ & 6 & 23.1 & 11 & 8.5 \\
\hline $\begin{array}{c}\text { No, but tourism is included } \\
\text { within the overall master plan } \\
\text { for the community }\end{array}$ & 13 & 50.0 & 48 & 37.2 \\
\hline No, no plan for tourism exists & 5 & 19.2 & 31 & 24.0 \\
\hline Unsure & 2 & 7.7 & 39 & 30.2 \\
\hline
\end{tabular}

Mean scores suggest that identifying and implementing sustainability initiatives are currently engaged in 'somewhat' by both groups of respondents, ranking ninth of the eleven activities for CVB directors (mean 2.8) and fourth for planning officials (3.0). Place making, and contributing to economic development, the protection of sensitive natural areas, and the preservation of cultural heritage - all of which could be interpreted as important dimensions of a sustainable approach - for the most part scored more highly, however (means 2.73.5 for CVBs and 3.0-3.4 for planners).

Table 5. Extent to Which Organization Should Engage in Activities (n and (\%), CVBs (top of each row) and planning officials (bottom of row))

\begin{tabular}{c|c|c|c|c|c|c}
\hline & Not At All & A Little & Somewhat & $\begin{array}{c}\text { To a Great } \\
\text { Extent }\end{array}$ & $\begin{array}{c}\text { Mean } \\
\text { (out of 4) }\end{array}$ & Unsure \\
\hline Tourism marketing & 0 & $1(2.8)$ & $1(2.8)$ & $34(94.4)$ & $3.9^{* *}$ & 0 \\
& $40(31.0)$ & $30(23.3)$ & $36(27.9)$ & $21(16.3)$ & $2.3^{* *}$ & $2(1.6)$ \\
\hline Enhancing visitors' experiences & 0 & $2(5.6)$ & $3(8.3)$ & $31(86.1)$ & $3.8^{* *}$ & 0 \\
& $7(5.4)$ & $23(17.8)$ & $53(41.10$ & $44(34.1)$ & $3.1^{* *}$ & $2(1.6)$ \\
\hline Attracting conventions and other & $1(2.8)$ & $4(11.1)$ & $6(16.7)$ & $25(69.4)$ & $3.5^{* *}$ & 0 \\
events & $42(32.6)$ & $34(26.4)$ & $27(20.9)$ & $24(18.6)$ & $2.3^{* *}$ & $2(1.6)$ \\
\hline Anticipating/managing crises & $2(5.6)$ & $5(13.9)$ & $9(25.0)$ & $20(55.6)$ & 3.3 & 0 \\
\hline Tourism planning & $12(9.3)$ & $12(9.3)$ & $32(24.8)$ & $72(55.8)$ & 3.3 & $1(0.8)$ \\
\hline Identifying/implementing & 0 & $1(2.8)$ & $4(11.1)$ & $30(83.3)$ & $3.8^{* *}$ & $1(2.8)$ \\
sustainability initiatives & $21(16.3)$ & $42(32.6)$ & $38(29.5)$ & $27(20.9)$ & $2.6^{* *}$ & $1(0.8)$ \\
\hline Coordinating/building partnerships & $1(0.8)$ & $4(11.1)$ & $14(38.9)$ & $16(44.4)$ & $3.2^{*}$ & 0 \\
with tourism stakeholders & $12(9.3)$ & $27(20.9)$ & $35(27.1)$ & $55(42.6)$ & $3.0^{* *}$ & 0 \\
\hline Place making (creating a better & 0 & $4(11.1)$ & $8(22.2)$ & $24(66.7)$ & 3.6 & 0 \\
place for residents and visitors) & $2(1.6)$ & $5(3.9)$ & $18(14.0)$ & $104(80.6)$ & 3.7 & 0 \\
\hline Contributing to economic & 0 & $1(2.8)$ & $9(25.0)$ & $21(69.4)$ & 3.7 & $1(2.8)$ \\
development & $2(1.6)$ & $6(4.7)$ & $27(20.9)$ & $91(70.5)$ & 3.6 & $3(2.3)$ \\
\hline Contributing to the protection of & $1(2.8)$ & $4(11.1)$ & $13(36.1)$ & $18(50.0)$ & $3.3^{*}$ & 0 \\
sensitive natural areas & $2(1.6)$ & $8(6.2)$ & $18(14.0)$ & $101(78.3)$ & $3.7^{*}$ & 0 \\
\hline Contributing to the preservation of & $1(2.8)$ & $3(8.3)$ & $10(27.8)$ & $21(58.3)$ & 3.5 & $1(2.8)$ \\
cultural heritage & $1(0.8)$ & $14(10.9)$ & $34(26.4)$ & $78(60.5)$ & 3.5 & $2(1.6)$ \\
\hline
\end{tabular}

\footnotetext{
$*$ means different at $0.05, * *$ means different at 0.01
} 
Table 6. Difference between extent to which organization currently engages and should engage in activities

\begin{tabular}{|c|c|c|c|c|}
\hline & \multicolumn{2}{|c|}{ CVBs } & \multicolumn{2}{|c|}{ Planning Officials } \\
\hline & Do & Should & Do & Should \\
\hline Tourism marketing & 3.9 & 3.9 & $2.0 *$ & $2.3 *$ \\
\hline Enhancing visitors' experiences & 3.7 & 3.8 & 2.8 & 3.1 \\
\hline Attracting conventions and other events & $3.1^{*}$ & $3.5^{*}$ & $1.7 * *$ & $2.3 * *$ \\
\hline Anticipating/managing crises & $2.6 * *$ & $3.3 * *$ & $2.9 * *$ & $3.3 * *$ \\
\hline Tourism planning & 3.6 & 3.8 & $2.2 * *$ & $2.6 * *$ \\
\hline $\begin{array}{c}\text { Identifying/implementing sustainability } \\
\text { initiatives }\end{array}$ & 2.8 & 3.2 & $3.0 * *$ & $3.6 * *$ \\
\hline $\begin{array}{l}\text { Coordinating/building partnerships with } \\
\text { tourism stakeholders }\end{array}$ & 3.8 & 3.9 & $2.7 * *$ & $3.0 * *$ \\
\hline $\begin{array}{l}\text { Place making (creating a better place for } \\
\text { residents and visitors) }\end{array}$ & 3.4 & 3.6 & $3.4 * *$ & $3.7 * *$ \\
\hline Contributing to economic development & 3.5 & 3.7 & $3.3 * *$ & $3.6 * *$ \\
\hline $\begin{array}{c}\text { Contributing to the protection of sensitive } \\
\text { natural areas }\end{array}$ & $2.7 *$ & $3.3 *$ & $3.3 * *$ & $3.7 * *$ \\
\hline $\begin{array}{c}\text { Contributing to the preservation of cultural } \\
\text { heritage }\end{array}$ & $2.9 *$ & $3.5^{*}$ & $3.0 * *$ & $3.5^{* *}$ \\
\hline
\end{tabular}

As anticipated given their differential functions, when asked about the extent to which their organization should engage in the series of activities (Table 5), there were significant differences between the CVB directors and the planning officials with respect to tourism marketing, enhancing visitors' experiences, coordinating/building partnerships with tourism stakeholders, and attracting conventions and other events (with mean scores higher for CVBs in all cases). CVB directors also recorded a significantly higher mean for tourism planning, though the caveat with regards to their interpretation of planning as described above still applies. It is concerning that the planning officials did not see this function as any more than a little to somewhat important (mean 2.6). Both groups saw place making and contributing to economic development, the protection of sensitive natural areas, and the preservation of cultural heritage as activities they should be engaging in somewhat to a great extent (means of 3.3 or greater), with the only significant difference across these four items being planning officials' greater concern for natural areas.

When comparing current with desirable levels of engagement within the two groups, the average score for the latter was the same (one case) or higher ( 21 cases) than for the former in every instance (Table 6). Those differences were significant for CVB directors for anticipating/managing crises, and contributing to the protection of sensitive natural areas and to the preservation of cultural heritage (increase of 0.6 points on the four-point scale) and for attracting conventions and other events ( 0.4 point increase). Notably, the survey was conducted prior to the January 2020 outbreak of coronavirus. CVB directors did not perceive any significant need to increase their engagement in tourism planning (though both means were relatively high) or, of more concern, in identifying/implementing sustainability initiatives. For planners, significant differences in means between current and desirable levels of engagement were noted for all activities other than the enhancement of visitors' experiences. Though identified as something planners should do more of, tourism planning nevertheless ranked ninth of the eleven activities on the should-do list.

\subsection{Understanding of sustainability}

Garrod and Fyall [34] observed that "defining sustainable development in the context of tourism has become something of a cottage industry in the academic literature of late". More than twenty years later, findings from this study suggest that the number and variety of conceptualisations among those involved in the planning and delivery of tourism and broader economic/community development remains high. The most commonly identified themes arising when respondents were asked to indicate what the term 'sustainable tourism' means to them are listed in Tables 7 and 8; the number of respondents indicating a lack of opinion or knowledge is also provided.

Table 7. Meaning of Sustainable Tourism - CVB Directors $(\mathrm{n}=32$, multiple responses allowed)

\begin{tabular}{cc}
\hline Item & n and \% of mentions \\
\hline Protecting/not harming resources/the & $14(43.8 \%)$ \\
environment & $7(21.9 \%)$ \\
Improving the area/community & $6(18.9 \%)$ \\
Attracting new/return visitors & $5(15.6 \%)$ \\
Today and into the future/long term & $2(6.3 \%)$ \\
approach & $1(3.1 \%)$ \\
Balance/balancing & \\
I don't know/understand this term &
\end{tabular}

Table 8. Meaning of sustainable tourism - planning officials $(\mathrm{n}=121$, multiple responses allowed)

\begin{tabular}{cc}
\hline Item & $\begin{array}{c}\text { n and \% of } \\
\text { mentions }\end{array}$ \\
\hline Attracting new/return visitors & $22(18.2 \%)$ \\
Protecting/not harming resources/the & $15(12.4 \%)$ \\
environment & $14(11.6 \%)$ \\
Year round (rather than seasonal) tourism & $8(6.6 \%)$ \\
Balance/balancing & $5(4.1 \%)$ \\
Considers residents and visitors equally & $5(4.1 \%)$ \\
Economic benefits without harm to the & \\
environment & $5(4.1 \%)$ \\
Today and into the future/long term & $5(4.1 \%)$ \\
approach & $1(0.8 \%)$ \\
Don't know (this term) & \\
Nothing &
\end{tabular}

The most frequently mentioned characteristic of sustainable tourism among CVB directors was the protection of resources/the environment (44\%); $22 \%$ spoke of improving the area or community. However, $19 \%$ of responses focused solely on attracting new or return visitors, suggesting that 
close to one-fifth of CVB directors' conceptions of sustainability remain focused exclusively on pro-growth criteria, reminiscent of the early boosterism and economic/industry approaches to tourism and beliefs in tourism's benefits. Thirteen percent of CVB directors' responses mentioned residents/citizens; $16 \%$ referenced future conditions or the long term/run; and, $6 \%$ used the word balance or balancing.

Among planning officials, the most common response $(18 \%)$ focused solely on the sustainability of visitation (maintaining/growing visitor numbers); another $12 \%$ pointed more specifically to the reduction of seasonality in the industry, whilst $3 \%$ referenced the need to maintain or improve visitor satisfaction and likelihood to recommend. Again, then, even among those well-versed in the language of planning and well-practiced in its implementation, a concerning proportion of respondents proposed a growthoriented approach to tourism and did not recognise the wider impacts of tourism or the potential for alternative approaches to tourism designed to maximise positives and mitigate negatives. Twenty-eight percent of planning officials' responses identified the importance of maintaining/protecting (or not damaging) assets/resources; however, only seven (6\%) included reference to the need to protect all three of the environment and society and economy, of which only two also mentioned the need to simultaneously consider visitors and industry and hosts. Sixteen percent of planners' responses mentioned residents/citizens; $16 \%$ referenced future conditions or the long term/run; and, $7 \%$ used the word balance or balancing.

More than one-fifth of respondents across both samples focused solely on quantitative elements of visitation in their reply, i.e., maintaining or growing the number of visitors and/or things for visitors to see and do, a very narrow and purely economics-driven conception of tourism as industry and of increasing visitor numbers as a source of growth. These responses mirror findings of an analysis of Turkish tourism ministers' statements about tourism, the highest proportion of which $(24 \%)$ were characterised as "economically driven and growth-oriented", highlighting rising tourist numbers and tourism income [35]. A similar focus on the economic dimensions of sustainability was observed in sustainable tourism policy across four levels of government in Greece [36], with economic issues prevailing "in occurrence, length and significance in discussions". In a study of Calgary, Victoria and San Francisco, factor analysis revealed that experiential (consumer/satisfaction-oriented) and economic goals were prioritised over those emphasising environmental or sociocultural considerations [10]. Beaumont and Dredge [37] also observed that most tourism officers take a pro-economic development stance. In the 8-10 years since the aforementioned studies were published - and despite the substantial volume of literature published on sustainability and growing recognition of overtourism not only amongst academics but also in the media and by the public - a complete lack of understanding of the broader meaning and implications of sustainability amongst at least one-fifth industry and practitioner representatives across the US state of Michigan appears evident.

More than $10 \%$ of planners and $40 \%$ of CVB directors provided responses pertaining solely to environmental aspects of sustainability, with no mention of economic or social dimensions. Bramwell and Lane highlighted the need to broaden the common conception of sustainability from a 'green' or 'environmental' issue to a more balanced understanding of the nature of sustainability in 2008 [38]. Forty-six percent of the 55 international, European and Spanish institutional documents reviewed in another study focused primarily on environmental rather than social (29\%) or economic (24\%) aspects of sustainability [16]. It would appear that broader awareness of sustainability - as a concept involving more than the environment - is more prevalent amongst planning officials than tourism office directors in Michigan, though understanding of its full depth and breadth is certainly still not common, as the next paragraph emphasises. As found by Farsari, Butler and Szivas amongst municipal-level tourism policymakers in Greece [36], sociocultural dimensions of sustainability were the least likely to be identified by either group. Approximately $16 \%$ of CVB directors and $22 \%$ of planning officials mentioned local people (e.g., residents, citizens, hosts) in their responses. Recognition of the importance of this group in the accomplishment of increasing sustainability is a vital precursor to their active inclusion throughout the planning process, something that has often been lacking in the past [12] and was less than ideal here.

No respondents included all the basic elements of most recognised definitions of sustainability in their responses (i.e., consideration of economic, sociocultural, and environmental factors; of a host of stakeholders including though not limited to tourists, residents, industry, and government; and, of conditions and experiences in both present and future timeframes). Three CVB directors (9\%) and seven planning officials $(6 \%)$ mentioned all three of the economy, environment and society. This compares to $25 \%$ of 38 interviewees (representing the industry, local government and various community organizations or institutions) across Calgary, Victoria and San Francisco who identified these three basic dimensions of sustainability [10]. Dinica [33] concluded that there was an "urgent need" for stakeholders to find common ground in their sustainability visions in a Dutch context; a common ground appears a similarly pressing need in Michigan.

\subsection{Responsibility for sustainable tourism planning}

Responsibility for planning for sustainable tourism in the community was clearly seen to lie at the local level across both groups of respondents and according to both unprompted and prompted survey items. When asked who/which agency(ies) the respondent thought hold(s) primary responsibility for planning for sustainable tourism in his/her community, all but one of the 31 responding CVB directors and $83 \%$ of planning officials listed one or more local entity. This included $65 \%$ of CVB directors who listed the CVB, 55\% local government (municipal/township/village/Downtown Development Authority), and 35\% the Chamber of Commerce. Among the planning representatives, $42 \%$ mentioned the CVB or tourism office, $42 \%$ some sort of local government, and $41 \%$ the Chamber of Commerce. Multiple responses were allowed and most respondents ( $72 \%$ of CVB directors and $75 \%$ of planning officials) identified more than one responsible organisation or set of individuals. Responses to a closed item on the survey page following the open-ended question can be seen in Table 9. 
Table 9. Responsibility for Planning for Sustainable Tourism (n and (\%), CVBs (top of each row) and planning officials (bottom of row) $)^{*}$

\begin{tabular}{c|c|c|c|c|c}
\hline & Not At All & A Little & Somewhat & To a Great Extent & $\begin{array}{c}\text { Mean } \\
\text { (out of 4) }\end{array}$ \\
\hline \multirow{2}{*}{ Local government } & 0.0 & $6(18.8)$ & $7(21.9)$ & $19(59.4)$ & 3.4 \\
& $5(4.1)$ & $17(14.0)$ & $47(38.8)$ & $52(43.0)$ & 3.2 \\
\hline \multirow{2}{*}{ County government } & $2(6.3)$ & $7(21.9)$ & $9(28.1)$ & $14(43.8)$ & 3.1 \\
& $8(6.6)$ & $25(20.7)$ & $52(43.0)$ & $36(29.8)$ & 3.0 \\
\hline \multirow{2}{*}{ State government } & $4(12.5)$ & $5(15.6)$ & $13(40.6)$ & $10(31.3)$ & 2.9 \\
& $5(4.1)$ & $29(24.0)$ & $54(44.6)$ & $33(27.3)$ & 3.0 \\
\hline \multirow{2}{*}{ The Convention and Visitors Bureau } & 0.0 & $3(9.4)$ & $4(12.5)$ & $25(78.1)$ & 3.7 \\
& $10(8.3)$ & $8(6.6)$ & $26(21.5)$ & $77(63.6)$ & 3.4 \\
\hline \multirow{2}{*}{ The Chamber of Commerce } & 0.0 & $12(37.5)$ & $7(21.9)$ & $13(40.6)$ & 3.0 \\
& $2(1.7)$ & $9(7.4)$ & $43(35.5)$ & $67(55.4)$ & 3.5 \\
\hline
\end{tabular}

* 'unsure' was provided as an answer option but no respondents selected it for any item

The above are positive findings given that local entities have the greatest ability to actively control tourism development and to mitigate its negative impacts within their geographic confines $[9,11,12,39]$, whereas a centralised approach is more likely to result in more generic and reactive policies [6]. Similarly, local-level governmental entities have been identified as having the greatest ability to coordinate and initiate collaboration between the many types of public, private and non-profit organisation that should be involved in tourism issues [40]. Nevertheless, Middleton and Hawkins [39] have questioned the ability of local level agencies to perform these functions due to a combination of lack of information, expertise and will. Limitations on fiscal and human resources are other well-known challenges [41] and concerns have also been articulated regarding lack of cooperation and synergy between government departments at the local level, as well as lack of communication and agreement between the public and the private sectors [40]. Some survey respondents did indeed identify potential challenges without any solicitation, e.g., in response to the open-ended question regarding responsibility for sustainable tourism planning, one planner noted "Traverse City Tourism, but they seem to just be charged with bringing more and more people without regard to sustainability."

The variety of entities mentioned by respondents, i.e., the recognition by most that many entities hold responsibility, suggest that the "joined-up" approach to building sustainability practices across local government entities, as advocated by Dredge, Ford and Whitford [42], would be a wise one to follow in Michigan. The master class those authors describe included councillors, planners and engineers from a variety of departments/ backgrounds including transportation and recreation/parks, with the goal of promoting a more comprehensive and collaborative approach to tourism management at the local level. Though precipitated by drivers unique to the Australian context, the proposed framework nonetheless remains appropriate here since it suggests a threepillared approach to the development, marketing and management of destinations, all driven by sustainability concepts. The work of Beaumont and Dredge [37], which analysed the effectiveness of three different types of network approach to local tourism governance in the context of sustainable tourism management, is also of relevance here. Specifically, that work compared and contrasted the relative (dis)advantages of council-led, industry-led and communityled networks, all of which exist in various forms across Michigan. Membership-based tourism offices (CVBs in this case) tend to focus on the interests of those members, with a capacity to influence beyond those members which is sometime somewhat limited [37], suggesting the need for additional involvement of organisations operating in larger circles and with broader remits.

State government was on average perceived as somewhat responsible for planning for sustainable tourism across both groups. CVBs considered themselves more responsible than Chambers, whereas planners perceived Chambers to hold more responsibility than CVBs. This is an interesting differential given that both types of entity ultimately share the same fundamental goal of promoting their community; increased collaboration and cooperation between the entities could do much to sway the understanding and uptake of a sustainability agenda amongst their respective constituents. Dredge, Ford and Whitford [42] emphasise the desirability of collaboration via issue-based networks over "go-it-alone" policies, suggesting the need for Michigan's CVBs and Chambers to work together towards what should ideally be a common sustainability-driven goal. Wray [43] highlighted the attributes (representativeness, ownership, learning and relationships) and conditions (trust, power and access to knowledge) needed to foster effective partnerships in strategic tourism planning. Her analysis of the implementation of a seven-stage stakeholder engagement procedure during twoyear-long strategic tourism planning processes in a pair of Australian regions found that a common transactive approach had quite different outcomes, however, which she attributed to the differential nature of the tourism organisations (as "enabler" versus "provider") and their relationships with stakeholder groups. Emphasis on the fostering of the characteristics and conditions most conducive to the building of productive partnerships is therefore clearly equally as critical as that of the dimensions of sustainability or any other content desired to be incorporated into plans.

\section{CONCLUSION}

The findings provide fascinating though concerning insight into the thinking currently dominating tourism and planning office(r)s across Michigan. Simpson [6] has previously noted that "sustainable tourism is easier to describe than to implement." However, even basic understanding of the essence of sustainability remains limited and divergent amongst two groups of stakeholders that are both absolutely core to the planning, development, marketing and management of tourism in the study area. This finding suggests that a transition to a truly sustainability-driven 
approach to tourism planning across the state will be unlikely without substantial education of tourism officers and local planners regarding the components, dimensions and importance of sustainability in a tourism context. The critical influence of terminology was also evident, with CVB directors apparently interpreting the survey's reference to planning very differently to that intended. In spite of the indicated importance of planning as a current activity by CVBs, a tourism-specific development and associated management plan for the community was consistently non-existent across those areas represented by respondents. As such, despite the growing prevalence of the suggestion that the role of the CVB should expand from a previously exclusive emphasis on marketing to a much broader and inclusive focus on management - which by definition includes planning as a critical function [44] - CVBs in Michigan currently appear unprepared to take on that much more expansive role. Indeed, when prompted to describe their purpose, no CVB directors made any mention of planning or sustainability. This suggests the need for a substantive shift in mindset if planning for sustainability is to become an embedded practice.

The observation that "Sustainability is an attractive but problematic concept" [45] appears to remain very much the case. Likewise, the need to translate the huge volume of sustainability-focused tourism research into practitioneroriented terms (e.g., via development of best practice documents), as suggested by Ruhanen fifteen years ago now, continues to persist. The findings suggest an urgent need to inform and educate those entities best placed to actively lobby for - and to be directly involved in the implementation of sustainability thinking and initiatives in the tourism planning realm. Needs suggested include a clear understanding of what sustainability is/means, the diversity of aspects and stakeholders a sustainability focus ideally incorporates, and how a sustainable approach can be infused into ongoing thinking about tourism in its current and future forms within a community. An outcome of the work presented here, for example, is a recently published best practices guide to sustainable tourism planning prepared by the Michigan Association of Planning in consultation with a large and diverse group of planning and tourism stakeholders [46]. The guide also draws on interviews conducted with the commissioners and developers of a handful of tourism plans from across the United States that were identified by the project team as truly encapsulating most of the elements critical to a well-rounded sustainability approach. While professional planning entities such as the American Planning Association are well placed to disseminate such information, the US also benefits from the extension system operated by the nation's more than 100 land-grant colleges and universities who are charged with the provision of non-formal education and learning activities to the residents of their states; such entities are especially well equipped to translate scientific knowledge into materials both useful to and usable by industry and planning professionals and pratitioners [47].

The exploratory analyses presented provide a snapshot of opinion at the current time, which was prior to the outbreak of the coronavirus (C19) pandemic in late 2019/early 2020. C19 has presented especially significant challenges for the tourism and hospitality sectors and the need to plan for the recovery of tourism, and the associated opportunity to rethink the way in which tourism operates, are clearly evident. Revisitation of these issues at a future point will allow assessment of any changes in the levels of awareness and understanding of, and engagement with, sustainability principles and practices to be measured. A reanalysis would be especially desirable in the context of the publication of the best practices guide referenced above. The analyses also reflect a single US state, and whilst there is no reason to anticipate that Michigan is performing substantially better or worse in this realm than most other US states the generalisability of these findings to other nations is hard to gauge. Similar evaluations across different states and nations would be desirable.

Social network analysis has shown that DMOs tend to enjoy very central positions in tourism stakeholder networks, and that they are perceived to hold high levels of legitimacy by other stakeholders; these perceptions imbue them with substantial power and the ability to influence others [48]. Focusing on these and other local entities in the drive towards greater embedding of sustainability principles into the tourism planning process is therefore intuitive given their collective responsibilities for implementing plans and policies and enforcing regulations [49]. Nevertheless, as those and other authors point out, achievement of a truly sustainability-driven approach to tourism planning and management requires the involvement of a wide-ranging collection of industry and community stakeholders with divergent interests, goals, values and perspectives $(10,48,49]$. One critical group not considered here was destination residents; incorporation of their opinions would provide a more rounded understanding of the various viewpoints concerning sustainability in tourism planning. Similarly, commercial interests - a vital component in terms of the day-to-day implementation of sustainability practices - were not surveyed. With respect to the types of governmental organisation that were invited to participate, only local and county entities were considered; no state, national or international agency opinions were sought (all of which are relevant given Michigan's expansive system of state lands, multiple national parks and similar designations, and extensive border with neighbouring Canada).

\section{REFERENCES}

[1] Hall, C.M., Dayal, N., Majstorović, D., Mills, H., PaulAndrews, L., Wallace, C., Truong, V.D. (2016). Accommodation consumers and providers' attitudes, behaviours and practices for sustainability: A systematic $\begin{array}{lll}\text { review. } & \text { Sustainability, } & 8(7) \text { : }\end{array}$ https://doi.org/10.3390/su8070625

[2] Higgins-Desbiolles, F., Moskwa, E., Wijesinghe, G. (2019). How sustainable is sustainable hospitality research? A review of sustainable restaurant literature from 1991 to 2015. Current Issues in Tourism, 22(13): 1551-1580. https://doi.org/10.1080/13683500.2017.1383368

[3] Kim, S.H., Lee, K., Fairhurst, A. (2017). The review of "green" research in hospitality, 2000-2014: Current trends and future research directions. International Journal of Contemporary Hospitality Management, 29(1): 226-247. https://doi.org/10.1108/IJCHM-11-2014-0562

[4] Connell, J., Page, S.J., Bentley, T. (2009). Towards sustainable tourism planning in New Zealand: Monitoring local government planning under the Resource Management Act. Tourism Management, 30(6): 867-877. https://doi.org/10.1016/j.tourman.2008.12.001

[5] Ruhanen, L. (2008) Progressing the sustainability debate: A knowledge management approach to sustainable 
tourism planning. Current Issues in Tourism, 11(5): 429455. https://doi.org/10.1080/13683500802316030

[6] Simpson, K. (2001). Strategic planning and community involvement as contributors to sustainable tourism development. Current Issues in Tourism, 4(1): 3-41. https://doi.org/10.1080/13683500108667880

[7] Michael Hall, C. (2008). Tourism Planning: Policies, Processes and Relationships. Prentice Hall.

[8] Getz, D. (1987) Tourism planning and research: Traditions, models and futures, Strategic Planning for Tourism: An Australian Travel Research Workshop. Lord Forrest Hotel, Bunbury, Western Australia: Conference Papers and Workshop Notes, pp. 2-43.

[9] Godfrey, K.B. (1998). Attitudes towards 'sustainable tourism' in the UK: A view from local government. Tourism Management, 19(3): 213-224. https://doi.org/10.1016/S0261-5177(98)00020-X

[10] Timur, S., Getz, D. (2009). Sustainable tourism development: How do destination stakeholders perceive sustainable urban tourism? Sustainable Development, 17(4): 220-232. https://doi.org/10.1002/sd.384

[11] Ruhanen, L. (2004). Strategic planning for local tourism destinations: An analysis of tourism plans. Tourism and Hospitality Planning \& Development, 1(3): 239-253. https://doi.org/10.1080/1479053042000314502

[12] Ruhanen, L. (2013). Local government: Facilitator or inhibitor of sustainable tourism development? Journal of $\begin{array}{lll}\text { Sustainable } \quad \text { Tourism, } & \text { 21(1): }\end{array}$ https://doi.org/10.1080/09669582.2012.680463

[13] Baggio, R., Marzano, G. (2007). Destination management plans: use of language as representation of power. 17th Annual Conference of the Council for Australian University Tourism and Hospitality Education, Sydney, Australia.

[14] Moyle, B.D., McLennan, C.L.J., Ruhanen, L., Weiler, B. (2014). Tracking the concept of sustainability in Australian tourism policy and planning documents. Journal of Sustainable Tourism, 22(7): 1037-1051. https://doi.org/10.1080/09669582.2013.839694

[15] Simão, J.N., Partidário, M.D.R. (2012). How does tourism planning contribute to sustainable development? Sustainable Development, 20: 372-385. https://doi.org/10.1002/sd.495

[16] Torres-Delgado, A., Palomeque, F.L. (2012). The growth and spread of the concept of sustainable tourism: The contribution of institutional initiatives to tourism policy. Tourism Management Perspectives, 4: 1-10. https://doi.org/10.1016/j.tmp.2012.05.001

[17] Gössling, S., Hansson, C.B., Hörstmeier, O., Saggel, S. (2002). Ecological footprint analysis as a tool to assess tourism sustainability. Ecological Economics, 43(2-3): 199-211. https://doi.org/10.1016/S0921-8009(02)002112

[18] Becken, S., Simmons, D. (2008). Using the concept of yield to assess the sustainability of different tourist types. Ecological Economics, 67(3): 420-429. https://doi.org/10.1016/j.ecolecon.2007.12.025

[19] Castellani, V., Sala, S. (2010). Sustainable performance index for tourism policy development. Tourism Management, $31(6)$ : 871-880. https://doi.org/10.1016/j.tourman.2009.10.001

[20] Ko, T.G. (2005). Development of a tourism sustainability assessment procedure: A conceptual approach. Tourism Management, 26(3):

431-445 https://doi.org/10.1016/j.tourman.2003.12.003

[21] Miller, G. (2001). The development of indicators for sustainable tourism: Results of a Delphi survey of tourism researchers. Tourism Management, 22(4): 351362. https://doi.org/10.1016/S0261-5177(00)00067-4

[22] Roberts, S., Tribe, J. (2008). Sustainability indicators for small tourism enterprises - An exploratory perspective. Journal of Sustainable Tourism, 16(5): 575-594. https://doi.org/10.1080/09669580802159644

[23] Tsaur, S.H., Lin, Y.C., Lin, J.H. (2006). Evaluating ecotourism sustainability from the integrated perspective of resource, community and tourism. Tourism Management, 27(4): 640-653. https://doi.org/10.1016/j.tourman.2005.02.006

[24] Choi, H.C., Sirakaya, E. (2006). Sustainability indicators for managing community tourism. Tourism Management, 27(6): 1274-1289. https://doi.org/10.1016/j.tourman.2005.05.018

[25] Blancas, F.J., Lozano-Oyola, M., González, M., Guerrero, F.M., Caballero, R. (2011). How to use sustainability indicators for tourism planning: The case of rural tourism in Andalusia (Spain). Science of the Total Environment, 412-413: 28-45. https://doi.org/10.1016/j.scitotenv.2011.09.066

[26] García-Melón, M., Gómez-Navarro, T., Acuña-Dutra, S. (2012). A combined ANP-delphi approach to evaluate sustainable tourism. Environmental Impact Assessment Review, 34: 41-50. https://doi.org/10.1016/j.eiar.2011.12.001

[27] Huang, Y.L., Luo, S.F., Cheng, D.P. (2009). Assessment on the capability of sustainable development in agritourism destination based on genetic algorithm optimization - Taking southwest ethnic areas as an example. Tourism Tribune, 10: 013 .

[28] Zhang, J., Ji, M., Zhang, Y. (2015). Tourism sustainability in Tibet - Forward planning using a systems approach. Ecological Indicators, 56: 218-228. https://doi.org/10.1016/j.ecolind.2015.04.006

[29] Tourism Economics. (2018). Economic Impact of Tourism in Michigan, 2017. https://www.michigan.org/industry/research.

[30] SMARInsights (2019). Pure Michigan 2018 Advertising Effectiveness. https://www.michigan.org/industry/research.

[31] Associated Press. (2016). One of Michigan's best-kept natural secrets is struggling with too many tourists. https://skift.com/2016/06/27/one-of-michigans-bestkept-natural-secrets-is-struggling-with-too-manytourists/.

[32] Donnelly, F.X. (2018). Tourism helps and hurts town near Pictured Rocks. https://eu.detroitnews.com/story/news/local/michigan/2 018/07/17/tourism-problems-munising-pictured-rocksnational-lakeshore/776946002/.

[33] Dinica, V. (2009). Governance for sustainable tourism: A comparison of international and Dutch visions. Journal of Sustainable Tourism, 17(5): 583-603. https://doi.org/10.1080/09669580902855836

[34] Garrod, B., Fyall, A. (1998). Beyond the rhetoric of sustainable tourism? Tourism Management, 19(3): 199212. https://doi.org/10.1016/S0261-5177(98)00013-2

[35] Yüksel, A., Yüksel, F., Culha, O. (2012). Ministers' statements: A policy implementation instrument for sustainable tourism? Journal of Sustainable Tourism, 
20(4):

$513-532$

https://doi.org/10.1080/09669582.2011.617823

[36] Farsari, I., Butler, R.W., Szivas, E. (2011). Complexity in tourism policies: A cognitive mapping approach. Annals of Tourism Research, 38(3): 1110-1134. https://doi.org/10.1016/j.annals.2011.03.007

[37] Beaumont, N., Dredge, D. (2010). Local tourism governance: A comparison of three network approaches. Journal of Sustainable Tourism, 18(1): 7-28. https://doi.org/10.1080/09669580903215139

[38] Bramwell. B., Lane. B. (2008). Priorities in sustainable tourism research. Journal of Sustainable Tourism, 16(1): 1-4. https://doi.org/10.2167/09669580803489612

[39] Middleton, V.T., Hawkins, R. (1998). Sustainable Tourism: A Marketing Perspective. Oxford, UK and New York, USA: Routledge.

[40] Briedenhann, J. (2007). The role of the public sector in rural tourism: Respondents' views. Current Issues in Tourism, 10(6): https://doi.org/10.2167/cit331.0

[41] Dredge, D. (2001). Local government tourism planning and policy-making in New South Wales, Australia: Institutional development and historical legacies. Current Issues in Tourism, 4(2-4): 355-380. https://doi.org/10.1080/13683500108667893

[42] Dredge, D., Ford, E.J., Whitford, M. (2011). Managing local tourism: Building sustainable tourism management practices across local government divides. Tourism and Hospitality Research, 11(2): 101-116. https://doi.org/10.1057/thr.2010.064

[43] Wray, M. (2011). Adopting and implementing a transactive approach to sustainable tourism planning: Translating theory into practice. Journal of Sustainable Tourism, 19(4-5): 605-627. https://doi.org/10.1080/09669582.2011.566928

[44] Morrison, A.M. (2019). Marketing and Managing Tourism Destinations. Oxford, UK and New York, USA: Routledge.

[45] Ahn, B.Y., Lee, B.K., Shafer, C.S. (2002). Operationalizing sustainability in regional tourism planning: An application of the limits of acceptable change framework. Tourism Management, 23(1): 1-15. https://doi.org/10.1016/S0261-5177(01)00059-0

[46] Rampson, W., Nicholls, S. (Eds.) (2020). Master Planning for Tourism in Michigan. Ann Arbor, MI: Michigan Association of Planning. https://miapa.memberclicks.net/assets/images/Tourism/ Master\%20Planning\%20for\%20Tourism\%20in\%20Mic higan\%20web.pdf.

[47] United States Department of Agriculture National Institute of Food and Agriculture (no date). Extension. https://nifa.usda.gov/extension.

[48] Timur, S., Getz, D. (2008). A network perspective on managing stakeholders for sustainable urban tourism. International Journal of Contemporary Hospitality Management, 20(4): 445-461. https://doi.org/10.1108/09596110810873543

[49] Bell, S., Morse, S. (2004). Experiences with sustainability indicators and stakeholder participation: A case study relating to a 'Blue Plan' project in Malta. Sustainable Development, 12(1): 1-14. https://doi.org/10.1002/sd.225 